\title{
Impact of enriching larval brine shrimp (Artemia sp.) with a supplement containing polyunsaturated fatty acids on their growth and mortality
}

\author{
Maja Prusińska, Olga Kushniryk, Oleksii Khudyi, Lidiia Khuda, Ryszard Kolman
}

Received - 26 May 2015/Accepted - 23 July 2015. Published online: 31 October 2015; OInland Fisheries Institute in Olsztyn, Poland Citation: Prusińska M., Kushniryk O., Khudyi O., Khuda L., Kolman R. 2015 - Impact of enriching larval brine shrimp (Artemia sp.) with a supplement containing polyunsaturated fatty acids on their growth and mortality - Arch. Pol. Fish. 23: 149-154.

\begin{abstract}
The aim of the study was to determine the impact the commercial supplement S.presso (INVE Aquaculture, Belgium), a source of polyunsaturated fatty acids to enrich the proximate composition of brine shrimp (Artemia sp.), had on their growth and mortality. Four different enrichment protocols were investigated: the supplement was given in one or two doses at various time intervals. The results indicate that while S.presso increased nauplius mortality slightly, administering the appropriate dose reduced losses to a very low level (from $12.5 \%$ with a single dose to $8.6 \%$ with the recommended dose divided into to equal parts). Additionally, it was confirmed that the supplement S.presso increased brine shrimp growth slightly in comparison to that of the control group, but the differences were statistically insignificant. The results permit concluding that S.presso is suitable for use as a source of polyunsaturated fatty acids for brine shrimp enrichment with the intent of using them as fish food.
\end{abstract}

Keywords: Artemia, bioencapsulation, enrichment, essential fatty acids, live food, PUFA

\footnotetext{
M. Prusińska, [ $\Xi^{\circ}$, R. Kolman

Department of Ichthyology,

Inland Fisheries Institute in Olsztyn, Poland

10-719, Olsztyn-Kortowo, Poland, Oczapowskiego 10

Tel.:+48 8952401 71; e-mail: m.prusinska@infish.com

O. Kushniryk, O. Khudyi, L. Khuda

Department of Biochemistry and Biotechnology,

Yuriy Fedkovych Chernivtsi National University, Ukraine
}

\section{Introduction}

Laval brine shrimp (Artemia sp.) is one of the most frequently used first live foods in both industrial and amateur fish larviculture. Feeding larval fish nauplii instead of artificial feeds reduces fish mortality and accelerates growth rates and development (Léger et al. 1986). Artemia sp. is a relatively safe nutritional resource for very young fish which derive from it not only the nutritional components required for growth and development but also a range of enzymes that they are not yet able to synthesize effectively enough. Another important aspect supporting the use of brine shrimp is the ease with which this type of feed is prepared in any given quantity and at any time as required by rearing (Bengtson et al. 1991).

Despite the many advantages of Artemia sp. nauplii, there is one distinct disadvantage: it is not a nutritionally complete food because of its near total lack of polyunsaturated fatty acids (PUFA) $\omega-3$ such as docosahexaenoic acid (DHA) and eicosapentaenoic acid (EPA) (Navarro i Sargent 1992). These acids are formed during the desaturation and elongation of $\alpha$-linolenic acid (C18:3) (Sargent et. al. 1995); however, since fish are not capable yet of independent synthesis (Henderson 1996, Tocher 2003), these must be delivered

\footnotetext{
C Copyright by Stanisław Sakowicz Inland Fisheries Institute in Olsztyn.

(c) 2015 Author(s). This is an open access article licensed under the Creative Commons Attribution-NonCommercial-NoDerivs License (http://creativecommons.org/licenses/by-nc-nd/3.0/).
} 
externally by the food. Simultaneously, polyunsaturated fatty acids occupy one of the most important positions among biologically-active substances. They are not only the lipid building blocks of cell membranes, but they also participate in a range of important metabolic transformations that produce eicosanoids, including prostaglandins, prostacyclin, thromboxanes, and leukotrienes (Kim et al. 2002, Hrytsyniak et al. 2009).

The polyunsaturated fatty acid profile of lipids is significantly dependent on the type and quantity of feed consumed, which is why enriching early feed can permit balancing this profile. Feeding larval fish brine shrimp nauplii enriched with PUFA has an advantageous impact on fish growth and development, while simultaneously lowering mortality (Akbary et al. 2011, Prusińska et al. 2011, Chepurkina et. al. 2014), decreasing the number of skeletal anomalies (Cahu et al. 2003, Villeneuve et al. 2005, Lall and Lewis-McCrea 2007), positively impacting the development of the digestive tract (Kamaszewski et al. 2014a) and its enzymatic activity (Kamaszewski et al. 2014b), and increasing resistance to stress (Adloo et al. 2012). In addition to the advantages outlined above, bioencapsulation, the name of the process of enriching nauplii prior to feeding then to larval fish, also has significant disadvantages. As a rule, fish are fed nauplii immediately after hatching, but when using the bioencapsulation method time is required for the enrichment process, and this usually takes from several to 24 additional hours. During this period, the nauplii will probably molt once or more and pass into the next developmental stage of metanauplius that is larger (Sorgeloos et al. 2001). This is disadvantageous, especially when the fish being fed have exceptionally small snouts. The second problem that can occur with enrichment is higher mortality among brine shrimp that is caused by the supplement itself (Harel et al. 2002). In an attempt to resolve these problems, better methods are being sought continually by testing new supplements for enriching brine shrimp with PUFA (Southgate and Lou 1995, McEvoy et al. 1996, Tocher et al. 1997, Tinh et al. 1999); however, to date there are no publications addressing the impact of S.presso on larval brine shrimp.

Consequently, the aim of this study was to verify if enriching brine shrimp larvae with the commercial supplement S.presso increased growth rates and to determine what impact S.presso had on nauplius mortality.

\section{Materials and Methods}

Dry Artemia sp. cysts (INVE Aquaculture, Belgium) were incubated according to manufacturer recommendations as follows: the cysts were placed in 81 Weiss jars filled with brine solution $\left(30 \mathrm{~g} \mathrm{l}^{-1}\right)$ that were illuminated, oxygenated, and kept at a temperature of $28^{\circ} \mathrm{C}( \pm 1)$. After $24 \mathrm{~h}$ of incubation, the nauplii were collected and then enriched with an in vivo encapsulation method with the commercial supplement S.presso (INVE, Belgium) (Table 1) at a daily dose recommended by the manufacturer of $0.5 \mathrm{~g} \mathrm{l}^{-1}$ in brine solution $20 \mathrm{~g} \mathrm{l}^{-1}$.

Enrichment was also performed in 81 Weiss jars that were oxygenated and held at a temperature of $21^{\circ} \mathrm{C}$. The nauplii were enriched using several protocols for which four experimental groups were created (each one in three replicates), as follows: group 1 the daily dose of supplement was administered once at the beginning of bioencapsulation (h 0 ); group 2 the daily dose of supplement was administered in two equal portions at the beginning of bioencapsulation (h 0 ) and after $6 \begin{array}{lll}6 & \mathrm{~h} & \text { of }\end{array}$ bioencapsulation; group 3 - the daily dose of supplement was administered in two equal portions at the beginning of bioencapsulation (h 0 ) and after $12 \mathrm{~h}$ of bioencapsulation; group 4 - the daily dose of supplement was administered in two equal portions 6 and $12 \mathrm{~h}$ after the beginning of bioencapsulation. The control group (K) comprised nauplii held under the same conditions as the experimental groups, but with out S.presso supplementation.

Nauplius mortality was assessed at 6, 12, and 24 $h$ of the experiment with a Nikon SMZ-2T stereomicroscope. From each jar in which 
Table 1

S.presso composition according to the manufacturer (INVE Aquaculture, Belgium)

\begin{tabular}{|c|c|}
\hline Ingredients & Content \\
\hline Moisture (\%) & 58 \\
\hline Crude oils and fats (\%) & 33 \\
\hline Crude protein (\%) & 3 \\
\hline Crude ash (\%) & 1 \\
\hline Crude fiber (\%) & 0.5 \\
\hline Phosphorus (\%) & 0.2 \\
\hline Sodium (\%) & 0.2 \\
\hline Calcium (\%) & 0.1 \\
\hline$\Sigma \omega 3$ PUFA (mg g $\left.{ }^{-1} \mathrm{dwt}\right)$ & 150 \\
\hline DHA/EPA & 9 \\
\hline vitamin A (IU kg $\left.{ }^{-1}\right)$ & 110.00 \\
\hline vitamin $\mathrm{D}_{3}\left(\mathrm{IU} \mathrm{kg}^{-1}\right)$ & 10.000 \\
\hline vitamin $\mathrm{E}\left(\mathrm{mg} \mathrm{kg}^{-1}\right)$ & 5.400 \\
\hline vitamin $\mathrm{C}\left(\mathrm{mg} \mathrm{kg}^{-1}\right)$ & 8.000 \\
\hline $\operatorname{Zinc}\left(\mathrm{mg} \mathrm{kg}^{-1}\right)$ & 125 \\
\hline Selenium (mg kg $\left.{ }^{-1}\right)$ & 0.35 \\
\hline Ethoxyquin (mg kg ${ }^{-1}$ ) & 200 \\
\hline $\mathrm{BHA}\left(\mathrm{mg} \mathrm{kg}^{-1}\right)$ & 50 \\
\hline Propyl gallate $\left(\mathrm{mg} \mathrm{kg}^{-1}\right)$ & 50 \\
\hline
\end{tabular}

enrichment was being performed, a $1 \mathrm{ml}$ volume was collected randomly and placed in a plankton chamber, and the number of dead and live brine shrimp were counted. These samples were taken in three replicates. Mortality was expressed in the percentage of dead individuals of the total number of individuals in the examined volume of sample.

To determine the impact on nauplius growth rate, the brine shrimp were held in six 81 Weiss jars. S.presso was administered to three of the jars at a dose of $0.5 \mathrm{~g} \mathrm{l}^{-1}$ in two equal portions at the beginning of encapsulation $(0 \mathrm{~h})$ and after $6 \mathrm{~h}$. The remaining three jars were the control groups, and no supplement was administered. Samples of a volume of $1 \mathrm{ml}$ were collected from each of the Weiss jars, and these were preserved immediately in Lugol's solution. Samples were collected at the beginning of bioencapsulation $(0 \mathrm{~h})$, after $6 \mathrm{~h}$ of bioencapsulation
(6 h), and after $12 \mathrm{~h}$ of the experiment (12 h). The preserved samples were placed on Petri dishes and then photographed with the Nikon SMZ-2T stereo microscope coupled with a digital camera. The photographs were saved with an image analysis program that permitted taking length measurements of the nauplii. From each sample, 100 individuals were selected randomly for measurement (in total 300 individuals from each experimental variant were measured for a total of 1500 individuals).

The results were analyzed with single factor analysis of variance (ANOVA) for mortality, while two factor analysis of variance (ANOVA) was used to analyze changes in nauplius length over the course of the experiment; the level of significance was $\alpha \leq 0.05$.

\section{Results}

The results of the experiments indicate that supplementing S.presso in two portions at an interval of 12 $\mathrm{h}$ caused mortality in all brine shrimp. The highest mortality in the first $12 \mathrm{~h}$ of the experiment was the protocol variant in which the whole supplement dose was given at the beginning of bioencapsulation (12.5 $\pm 0.74 \%$ ) (Table 2).

Administering the supplement in two equal portions resulted in slightly lower mortality during the first $12 \mathrm{~h}$ of the experiment than did administering the supplement in a single dose. Enrichment caused nauplius mortality in all variants of the experiment in comparison to the control group, but the differences were minimal. In the best protocol, which is recommended, the supplement was administered in two portions (group 4), and the differences between the experimental and control groups was barely $0.8 \%$, which was statistically insignificant.

The results of the nauplii length measurements indicated that administering the supplement containing polyunsaturated fatty acids increases their growth in comparison to that in the control group (Table 3). The mean length of the brine shrimp from the control group was $594.86 \pm 73.01 \mu \mathrm{m}$, while that of the experimental group was $600.82 \pm 58.67 \mu \mathrm{m}$. 
Table 2

Mortality (\%) of Artemia sp. nauplii in different S. presso enrichment protocols

\begin{tabular}{lllll}
\hline \hline \multirow{2}{*}{ Experimental groups } & \multicolumn{3}{l}{ Time } & \\
\cline { 3 - 5 } \cline { 3 - 4 } & Enrichment protocols & $6 \mathrm{~h}$ & $12 \mathrm{~h}$ & $24 \mathrm{~h}$ \\
\hline \hline 1 & $0 \mathrm{~h}$ & $10.5 \pm 0.71^{\mathrm{a}}$ & $10.7 \pm 1.86^{\mathrm{a}}$ & $12.5 \pm 0.74^{\mathrm{a}}$ \\
2 & $0 \mathrm{~h}+6 \mathrm{~h}$ & $8.0 \pm 0.77^{\mathrm{b}}$ & $9.6 \pm 0.47^{\mathrm{c}}$ & - \\
3 & $0 \mathrm{~h}+12 \mathrm{~h}$ & $8.0 \pm 0.77^{\mathrm{b}}$ & $10.2 \pm 0.64^{\mathrm{b}}$ & $100.0^{\mathrm{b}}$ \\
4 & $6 \mathrm{~h}+12 \mathrm{~h}$ & $5.0 \pm 0.24^{\mathrm{b}}$ & $8.1 \pm 0.73^{\mathrm{c}}$ & $8.6 \pm 0.87^{\mathrm{a}}$ \\
Control & without enrichment & $5.0 \pm 0.24^{\mathrm{b}}$ & $7.6 \pm 0.63^{\mathrm{c}}$ & $7.8 \pm 0.84^{\mathrm{a}}$ \\
\hline \hline
\end{tabular}

Groups in the same column with different letter indexes differ significantly statistically $(\mathrm{P} \leq 0.05)$.

Table 3

Comparison of the length $(\mu \mathrm{m})$ of enriched and control Artemia sp. nauplii during bioencapsulation $(\mathrm{n}=1500)$

\begin{tabular}{lllll}
\hline \hline & & \multicolumn{2}{l}{ Time } & \\
\cline { 3 - 5 } Experimental groups & Enrichment protocol & $0 \mathrm{~h}$ & $6 \mathrm{~h}$ & $12 \mathrm{~h}$ \\
\hline \hline Enriched & $0 \mathrm{~h}+6 \mathrm{~h}$ & $451.50 \pm 51.81$ & $572.81 \pm 70.86$ & $600.82 \pm 58.67$ \\
Control & without enrichment & $451.50 \pm 51.81$ & $553.43 \pm 82.23$ & $594.86 \pm 73.01$ \\
\hline \hline
\end{tabular}

\section{Discussion}

Performing brine shrimp enrichment according to four different experimental protocols led to the conclusion that administering the supplement in one dose at the beginning of bioencapsulation resulted in the highest mortality percentage during the first $12 \mathrm{~h}$ of the experiment. This phenomenon could have been caused by the fats in the supplement undergoing spontaneous transformation during enrichment (McEvoy et al. 1995, Navarro et al. 1999, Monroig et al. 2007). Polyunsaturated fatty acids oxidize using the oxygen in the supplement. The fatty acid oxidation products can also initiate processes linked to free radicals in the organisms (Viciano et al. 2013), which can effectively lead even to DNA damage (Przybyszewski et al. 2005). It is also likely that the supplement, which is comprised mainly of fats that leave a fatty film on everything, blocked the breathing apparatuses of the nauplii rendering it difficult for them to take up oxygen. This phenomenon could also retard gas exchange in the nauplii and cause mortality through a lack of oxygen. The mortality recorded in this experiment was relatively low in comparison to that obtained using different supplements. Harel et al. (2002) report 18\% mortality during enrichment lasting $16 \mathrm{~h}$ in a brine with a concentration of $20 \mathrm{gl}^{-1}$. Immediately following hatching, instar 1 nauplii are not yet able to take up the supplement fast enough to lower its ambient concentration; however, with growth and development they become increasingly capable of doing this (Figueiredo et al. 2009). Consequently, they filter the suspension more effectively so supplement concentrations do not reach levels that cause mortality. Additionally, administering the supplement in two portions as recommended by the manufacturer permits the nauplii to more effectively remove the substance from the environment, which decreases mortality. On the other hand, administering the supplement in one dose is less labor intensive, which could be significant when rearing is done on a semi- or fully industrial scale. The most advantageous protocol, with respect to nauplius mortality, appeared to be administering the supplement in two portions at an interval of $6 \mathrm{~h}$ from the beginning of incubation, even if this lengthens the time required for the entire procedure. This also allows the nauplii to grow larger, which can be undesirable when feeding fish with small snouts (Léger et al. 1987, Sorgeloos et al. 2001).

The results of this study indicate that while enrichment with S.presso has a negative impact on the 
mortality of nauplii, an enrichment protocol can be chosen that will reduce losses to a minimum. It is recommended to administer S.presso in two portions of $0.25 \mathrm{~g} \mathrm{l}^{-1}$ at $6 \mathrm{~h}$ intervals during an encapsulation period of $18 \mathrm{~h}$ counting from the moment of hatching. Enriching brine shrimp nauplii with S.presso did not result in a significant increase in length growth in comparison to the group that was not subjected to enrichment.

Author contributions. M.P. designed experiments and methods, directed implementation of study, M.P. and O.Ku. did all experiment procedures, R.K. supervised experiments, O.Ku. and M.P. statistically analyzed the data, M.P. and O.K. prepared the manuscript, L.K and O.Kh. helped to conduct the literature review, R.K., L.K and O.Kh. reviewed the article.

\section{References}

Adloo M.N., Matinfar A., Sourinezhad I. 2012 - Effects of feeding enriched Artemia franciscana with HUFA, vitamin $\mathrm{C}$ and $\mathrm{E}$ on growth performance, survival and stress resistance of yellowfin sea bream larvae - J. Aquacult. Res. Dev. 3: 157 doi:10.4172/2155-9546.1000157.

Akbary P., Hosseini S.A., Imanpoor M.N. 2011 - Enrichment of Artemia nauplii with essential fatty acids and vitamin C: effect on rainbow trout (Oncorhynchus mykiss) larvae performance - Iran. J. Fish. Sci. 10: 557-569.

Bengtson D.A., Léger P., Sorgeloos P. 1991 - Use of Artemia as a food source for aquaculture - In: Artemia Biology (Eds) R.A. Broune, P. Sorgeloos, C.N.A. Trotman, CRC Press, Boca Raton, FL: 255-280.

Cahu C., Infante J.Z., Takeuchi T. 2003 - Nutritional components affecting skeletal development in fish larvae Aquaculture 227: 245-258.

Chepurkina M. A., Gilyeva E.A., Prusińska M., Kolman R. 2014 - The use of the live feed enrichment method in sturgeon aquaculture - Vestnik Rybohoz'aystvennoy Nauki 4: 78-90 (in Russian).

Figueiredo J., van Woesik R., Lin J., Narciso L. 2009 Artemia franciscana enrichment model. How to keep them small, rich and alive? - Aquaculture 294: 212-220.

Harel M., Koven W., Lein I., Bar Y., Behrens P., Stubblefield J., Zohar Y., Place A.R. - 2002 - Advanced DHA, EPA and ArA enrichment materials for marine aquaculture using single cell heterotrophs - Aquaculture 213: 347-362.
Henderson R.J. 1996 - Fatty acid metabolism in freshwater fish with particular reference to polyunsaturated fatty acids - Arch. Anim. Nutr. 49: 5-22.

Hrytsyniak I., Smolyaninov K., Yanovich D., Vudmaska I., Yanovich V. 2009 - The biological role of $\omega$-3 polyunsaturated fatty acids and the peculiarities of their metabolism in freshwater fish - Fishery Science of Ukraine 1: 83-87 (in Russian).

Kamaszewski M., Ostaszewska T., Prusińska M., Kolman R., Chojnacki M., Zabytyvskij J., Jankowska B., Kasprzak R. 2014a - Effects of Artemia sp. enrichment with essential fatty acids on functional and morphological aspects of the digestive system in Acipenser gueldenstaedtii larvae Turk. J. Fish. Aquat. Sci. 14: 1-10.

Kamaszewski M., Wójcik M., Ostaszewska T., Kolman R., Prusińska M. 2014b - The effect of essential fatty acid (EFA) enrichment of Artemia sp. nauplii on the enzymatic activity of Atlantic sturgeon (Acipenser oxyrinchus Mitchill, 1815) larvae - preliminary study - J. Appl. Ichthyol. 2014: 1-3.

Kim H.-J., Myiazaki M., Ntambi J.M. 2002 - Dietary cholesterol oppose PUFA-mediated repression of the stearoyl-CoA desaturase-1 gene by SREBP-1 independent mechanism - J. Lipid Res. 43: 1750-1752.

Lall S.P., Lewis-McCrea L.M. 2007 - Role of nutrients in skeletal metabolism and pathology in fish - an overview Aquaculture 267: 3-19.

Léger P., Bengtson D.A., Simpson K.L., Sorgeloos P. 1986 The use and nutritional value of Artemia as a food source - Oceanogr. Mar. Biol. Ann. Rev. 24: 521-623.

Léger P., Bengtson D.A., Sorgeloos P., Simpson K.L., Beck A.D. 1987 - The nutritional value of Artemia: a review In: Artemia Research and its Applications. Vol. 3. Ecology, Culturing, Use in aquaculture (Eds) P. Sorgeloos, D.A. Bengtson, W. Decleir, E. Jaspers, Universa Press, Wetteren, Belgium: 357-372.

McEvoy L.A., Navarro J.C., Bell J.G., Sargent J.R. 1995 Autoxidation of oil emulsions during the Artemia enrichment process - Aquaculture. 134: 101-112.

McEvoy L.A., Navarro J.C., Hontoria F., Amat F., Sargent J.R. 1996 - Two novel Artemia enrichment diets containing polar lipid - Aquaculture 144: 339-352.

Monroig O., Navarro J.C., Amat F., Gonzales P., Hontoria F. 2007 - Oxidative stability and changes in the particle size of liposomes used in the Artemia enrichment Aquaculture 266: 200-210.

Navarro J.C., Henderson R.J., McEvoy L.A., Bell M.V., Amat F. 1999 - Lipid conversions during enrichment of Artemia - Aquaculture 174: 155-166.

Navarro J.C., Sargent J.R. 1992 - Behavioural differences in starving Clupea harengus L. larvae correlate with body levels of essential fatty acids. - J. Fish Biol. 41: 509-513.

Prusińska M., Chepurkina M., Wiszniewski G., Duda A., Kolman R. 2011 - Preliminary results of rearing larval 
Russian sturgeon (Acipenser gueldenstaedtii) fed live enriched feed - In: New species in aquaculture. Reproduction, rearing, prophylactics. (Eds.) Z. Zakęś, K. Demska-Zakęś, A. Kowalska, Wyd. IRS, Olsztyn: 45-52. (in Polish).

Przybyszewski W.M., Kasperczyk J., Stokłosa K., Bkhiyan A. 2005 - DNA damage induced by products of lipid peroxidation - Post. Hig. Med. Dosw. 59: 75-81 (in Polish).

Sargent J.R., Bell J.G., Henderson R.J., Tocher D.R. 1995 Requirement criteria for essential fatty acids - J. Appl. Ichthyol. 11: 183-198.

Sorgeloos P., Dhert P., Candrevaet P. 2001 - Use of the brine shrimp, Artemia spp., in marine fish larviculture Aquaculture 200: 147-159.

Southgate P.C., Lou D.C. - 1995 - Improving the n3 - HUFA composition of Artemia using microcapsules containing marine oils - Aquaculture 134: 91- 99.
Tinch L., Renaud S.M., Parry D.L. 1999 - Evaluation of recently isolated Australian tropical microalgae for the enrichment of the dietary value of the brine shrimp, Artemia nauplii - Aquaculture 170: 161-173.

Tocher D. 2003 - Metabolism and functions of lipids and fatty acids in teleost fish - Rev. Fish. Sci. 11: 107-184.

Tocher D.R., Mourente G., Sargent J.R. 1997 - The usage of silages prepared from fish neural tissues as enrichers for rotifers (Brachionus plicatilis) and Artemia in the nutrition of larval marine fish - Aquaculture 148: 213-231.

Viciano E., Monroig O., Salvador A., Amat J., Fiszman S., Navarro J.C. 2013 - Enriching Artemia nauplii with a high DHA-containing lipid emulsion: search for an optimal protocol - Aquac. Res. 46: 1-12.

Villeneuve L., Gisbert E., Delliou H.L., Cahu C.L., Zambonino - Infante J.L. 2005 - Dietary levels of all-trans retinol affect retinoid nuclear receptor expression and skeletal development in European sea bass larvae - Brit. J. Nutr. 93: 791-801. 